\title{
Difficulties Faced by College Students in Innovation and Entrepreneurship and Its Countermeasures*
}

\author{
Junliang Kong \\ Youth League Committee \\ Zhuhai College of Jilin University \\ Zhuhai, China 519041 \\ Yuanyuan Pan \\ Office of Academic Research \\ Zhuhai College of Jilin University \\ Zhuhai, China 519041 \\ Tingting Hong \\ Office of Academic Research \\ Zhuhai College of Jilin University \\ Zhuhai, China 519041
}

Yushi Lu

Office of Academic Research

Zhuhai College of Jilin University

Zhuhai, China 519041

Huize Luo

Office of Academic Research Zhuhai College of Jilin University

Zhuhai, China 519041

Kaihang Hong

Office of Academic Research

Zhuhai College of Jilin University

Zhuhai, China 519041

\author{
Yaomin Mei \\ Office of Academic Research \\ Zhuhai College of Jilin University \\ Zhuhai, China 519041
}

Xin $\mathrm{He}$

Office of Academic Research

Zhuhai College of Jilin University Zhuhai, China 519041

Zhimin Chen

Office of Academic Research Zhuhai College of Jilin University Zhuhai, China 519041

\section{Guanglei Huang}

Office of Academic Research Zhuhai College of Jilin University Zhuhai, China 519041

\section{Teng $\mathrm{Wu}$}

Office of Academic Research Zhuhai College of Jilin University Zhuhai, China 519041

\section{Zhicheng Chen}

Office of Academic Research Zhuhai College of Jilin University Zhuhai, China 519041

\begin{abstract}
As the forerunners of the times, college students actively responded to the call of the Party Central Committee for "mass entrepreneurship and innovation", setting off a wave of entrepreneurship. However, independent innovation and entrepreneurship also means a lot of suffering, and various internal and external factors hinder their entrepreneurial success. This paper finds ways to solve these problems, such as simple organizational structure, poor teamwork ability, single entrepreneurial form and source of funds, insufficient social support and other difficulties and reasons of the entrepreneurial team of college students' innovation and entrepreneurship, and puts forward relevant
\end{abstract}

*Fund: Research on the reform of the research and innovation mechanism of applied high-level universities (2018JZCQ04), the 2018 annual innovation project of Zhuhai College of Jilin University. opinions and suggestions.

Keywords-college students; innovation and entrepreneurship; difficulties; protection

\section{INTRODUCTION}

Entrepreneurship education is necessary for easing employment pressure, the social transformation, and the promotion of college students. In 2015, Premier Li Keqiang proposed "mass entrepreneurship and innovation" in the government work report. And governments at all levels introduced a series of self-employment and flexible employment policies. More and more college students choose to start their own businesses, setting off innovation 
and entrepreneurship boom among college students. At the same time, college students have encountered many problems in innovation and entrepreneurship. As for how to solve these problems reasonably, the higher education institution with high level of talent training is necessary to consider creating a good environment for college students to make the innovation and start a business. Therefore, this paper studies and explores the difficulties faced by college students in innovation and entrepreneurship, and proposes solutions to these problems.

\section{THE BACKGROUND AND SIGNIFICANCE OF COLLEGE STUDENTS' INNOVATION AND ENTREPRENEURSHIP}

In 1999, the graduates of major universities in China have increased. Enrollment expansion in colleges and universities has made employment more prominent and the employment situation has become more severe. More and more graduates are hard to find a satisfactory job, and even some graduates directly face the embarrassing situation of "graduation being equal unemployment". They can't find a job and can only sigh in the middle of the night. Under such circumstances, self-innovation and self-employment is a good choice. It is better to be able to make a grand vision than to be obsessed with life. There are also "halo effects" brought about by the exemplary characters such as Dong Mingzhu and Ma Yun. More and more college students take them as benchmarks and are eager to become great pioneers like them. In addition, the education received by students in colleges and universities, the various professional knowledge and skills they have learned, and the courage and daring spirit that young people generally have become a stepping stone on their road of entrepreneurship and innovation. Furthermore, there are reliable studies showing that the higher the level of entrepreneurship and innovation is, the higher the economic growth rate and employment rate will be. The entrepreneurship and innovation is conducive to promoting scientific and technological innovation and relieving employment pressure. On June 4, 2016, the executive meeting of State Council chaired by Premier Li Keqiang decided to vigorously promote the policy of mass entrepreneurship and innovation, and strive to increase the vitality of the enterprise and expand the new world of development. In recent years, China has paid more attention to the cultivation of national entrepreneurship and innovation ability, especially for the active group of college students. College students are full of confidence and have the spirit of "new born calves being not afraid of tigers", and these are precisely the qualities that an entrepreneur should possess. Therefore, college students' entrepreneurship and innovation has received strong support from universities, governments and society. Entrepreneurship education has also received attention in the field of education. How to effectively carry out entrepreneurship education and improve students' entrepreneurial intentions has become an important issue worthy of further discussion. The Ministry of Education, the Ministry of Personnel and other ministries of China have successively issued a series of policies to guide college students' independent innovation and self-employment, which has played a positive role in promoting college students' entrepreneurship and innovation. Against such a background, weighing the advantages and disadvantages, independent innovation and self-employment is very beneficial. Many college students are willing to develop towards the road of innovation and entrepreneurship.

College students' innovation and entrepreneurship are effective, which is of great significance. Investigating its roots, the college students of entrepreneurship and innovation who can choose to do things that suit their personality and their own interests and are more successful, so that they can combine their interests and dreams. It is necessary to know that when people are doing things that they are interested in, they can always devote themselves wholeheartedly to the realm of forgetting things, which can greatly improve work efficiency and maximize the value of life. In addition, independent innovation and selfemployment also provide opportunities for college students to express themselves and improve themselves. Under the severe employment situation, many graduates can find a job that is not professional. Through innovation and entrepreneurship, they can choose the relevant work with their professional advantages, and apply the theoretical knowledge they have learned to practice. This will make use of it, and the four years of university study will not be wasted. Due to the lack of social experience and professional experience, especially the lack of interpersonal relationships, college students will encounter various problems in the entrepreneurial process, especially in the early stage. After all, "paper will sleep shallow, never know the matter want to practice." After going through the general meeting, it isn't hard to understand that there is hardship or difficulty behind success. In the face of difficulties, college students can cultivate stubborn will and hard work spirit by not giving up try to solve problems and learn from their own deficiencies and shortcomings, check for missing vacancies, and finally become the talents of full-fledged development. For the whole society, college students' innovation and entrepreneurship are conducive to alleviating the current extremely serious employment problems. A successful graduate of innovation and entrepreneurship will not only increase the employment pressure of the society, but will also provide jobs for the society through its own innovative entrepreneurial activities and ease employment pressure. In addition, if graduates want to succeed in business, they must fully consider the needs of the society and choose the direction of entrepreneurship according to social needs. It is beneficial for college students to unify their self-value and social value and make more contributions to the society.

\section{The Status QuO OF COLLEGE STUDENTS' INNOVATION AND ENTREPRENEURSHIP}

In the process of innovation and entrepreneurship education in colleges and universities, students' entrepreneurial awareness are still not strong, and most students prefer being comfortable. The concept of innovation and entrepreneurship education is not really integrated with the school's teaching system. Innovative education is often in an independent state and is not included in the school's formal curriculum system. At present, college students in China are still in a state of "high enthusiasm and low 
practice". The proportion of entrepreneurs selected each year is only $5 \%$, and there is still a big gap comparing with the proportion of college students' entrepreneurship between $20 \%$ and $30 \%$ in developed countries. In the $5 \%$ of entrepreneurship, the average success rate of college students' entrepreneurship is only $3 \%$.

In most colleges and universities, innovation and entrepreneurship education is still a kind of marginal education, and it has not been included in the mandatory course. The curriculum system is imperfect and the syllabus is incomplete. The orientation of innovation and entrepreneurship education is not obvious and clear. Some college education does not recognize the essence of innovation and entrepreneurship education. It only trains students' knowledge and skills, but does not internalize entrepreneurial ideas into students' thoughts, or just introduces the concept of innovation in light of the courseware. Therefore, the entrepreneurial awareness of the college student group has not been fundamentally changed.

The concept of education cannot keep pace with the times. With the continuous promotion of the talent training mode and the reform of education and teaching in colleges and universities, the emphasis is on the instillation of professional theoretical knowledge, ignoring the theory and practice, and less implementing the traditional educational concept of practical internship. The theoretical knowledge is prior to the practice and implementation of the curriculum implementation model. The teaching model assisted and attached to the theory has been greatly improved. However, in the actual development of innovation and entrepreneurship education, the implementation is not thorough enough and not deep enough. At present, education and teaching still remain at the level of professionalism, systemicity and integrity of theoretical knowledge. Most of them still follow the traditional professional education implementation routine, with practice as the leading and experience-based training. Both the concept and the implementation model have not received sufficient attention and implementation.

The reform of the talent training model is not complete. The innovation and entrepreneurship education of college students is a complex and systematic talent training system. However, in most colleges and universities, the innovation and entrepreneurship education of college students has not yet been integrated into the talent training mode and the education and teaching system. There is no unified and implementable talent training program, which is often only used as a function of employment guidance services for college students. The integration of resource integration and implementation systems is not ideal. For example, most colleges and universities have established compulsory or elective courses for the "Professional Development and Employment Guidance for College Students" in accordance with the requirements of education. The innovative and entrepreneurial education covered in the course is only a course of 2-4 hours of entrepreneurship enlightenment and overview, and these courses often carry out relevant lectures or coaching reports in the form of the second class. There are also few talent training systems that effectively integrating innovation and entrepreneurship education into professional education and cultural quality education, and realizing the establishment of independent and formal courses. There are few, and there is no multi-level, three-dimensional curriculum system under the goal of unified talent training. In other words, the innovation and entrepreneurship education of college students has not been included in the implementation of the entire talent training system, and has not penetrated into all levels of personnel training.

Education and teaching content and form innovation are not enough. From the content of innovation and entrepreneurship education, it focuses on policy preaching, industry sharing, etc., with narrow content and single function. It has less emphasis on the cultivation of entrepreneurial ability and entrepreneurial practice training, so that students do not benefit from it, nor can they really start a business. In addition, the implementation model of education and teaching lacks the methods of interactive experiential training required by innovation and entrepreneurship education. It does not highlight the use and test of theory in the process of practice, as well as the formation of theoretical perspectives and innovation value.

\section{DIFFICULTIES AND REASONS FOR STARTING A BUSINESS}

\section{A. Difficulties Encountered in Starting a Business}

College students go to start a business with the unique advantages of college students, such as the youth and passion, but college students will inevitably encounter many difficulties in the process of starting a business

First of all, the psychological preparation of college students may not fully meet the requirements of entrepreneurship. Many college students have an entrepreneurial dream, but why are there so few people who can achieve it?

1) College students are not psychologically prepared at the beginning of their business: Most college students are not psychologically prepared for meeting the various setbacks encountered in entrepreneurship. The tenacious will is the cornerstone of entrepreneurship. The founder of KFC, Harlan Sanders, lost his job before founding KFC, searched everywhere, and sold his own fried chicken skill everywhere. It was because of this tenacious will that Sandoz successfully founded KFC.

2) College students lack capital accumulation: In addition to having sufficient psychological preparation, college students who want successful entrepreneurship also need the support of venture capital. Many college students just leave the campus and lack capital accumulation. Entrepreneurship needs funds. For entrepreneurs, there are three channels for funds: self-raised, borrowing, and the venture capital. The number of self-financing is limited; debit and credit is not easy, and is time-limited, which cannot meet the long-term investment needs of entrepreneurship; venture capital is the best form, especially suitable for college entrepreneurs. However, China's current 
venture capital market is still immature: first, there are fewer investors and limited funds; second, management is not standardized, and investment risks are high; third, listing conditions are high, investment cannot be extracted in time, and investment in other projects is continued. There are very few investors who can provide entrepreneurial entrepreneurship, and the number is limited.

3) Unreasonable use of funds: How to use the funds reasonably is also a big obstacle for college students to start a business. Many college students have the money, but they have incorrect budget estimation. Due to their lack of funds in the late stage of entrepreneurship, the project will be failed. There is the unreasonable team combination of college students. The personality collocation and role division of the entrepreneurial team members lead to the inefficiency of the entire entrepreneurial team. Some teams have insufficient social experience, and some teams lack the backbone. These are all encountered by college students when they start a team.

4) Entrepreneurial team has a simple organizational structure and poor teamwork ability: More than $80 \%$ of the entrepreneurial teams in some colleges and universities are made up of a professional classmate, and team members who are familiar with each other can better cooperate with each other. However, the entrepreneurial team members cannot be composed entirely of technicians or sales personnel. The operation of the entrepreneurial team requires talents of management, marketing, planning and other aspects.

5) Entrepreneurial form and source of funds are single, and social support is insufficient: The entrepreneurial field mainly focuses on catering, service industry and ecommerce, with low-tech content, and does not maximize the integration of the school's advantageous specialty and superior resources. The source of funds is mainly fundraising by students and financial support from school academies. There are fewer social capital inflows, and there are barriers to bank loans and other factors that limit college students' access to more financial support.

\section{B. Reasons Why College Students Encounter Difficulties in Starting a Business}

Entrepreneurship is a high-risk job, and the failure of entrepreneurship or encountering serious difficulties are normal. Na Guoyi, an expert on Drucker management and an independent director of China People's Insurance Co., Ltd., said in an interview that the failure of entrepreneurship mainly has the following four reasons.

There is no demand in the market, and start-ups will fail if they do not solve market problems. According to the findings of a professional company in the United States, solving interesting problems rather than satisfying market demand is the biggest cause of entrepreneurial failure, accounting for $42 \%$.

The second is the exhaustion of funds, and money and time are limited. Spending money is often linked to the failure of products that do not meet market and customer needs. Today, many startups, especially Internet startups, rely on venture capital to survive. Venture capital brings startup and development funds to entrepreneurs, which undoubtedly increases the chances of successful startups. At the same time, venture capital is also a double-edged sword. Because the venture capital is not the money of the startup, it is not cautious in the use of funds. It often causes the money to use up, and there is no new capital investment, so the startup company fails. The founder of a successful Internet company once said that they started to get $\$ 5$ million shortly after starting a business. As a result, they made the same mistakes that all startups had committed: starting to hire high-paying executives and setting high-value marketing promotion plan, and finally used up the money.

The third are team issues. A diverse team with a variety of skills is the key to entrepreneurial success. An important reason for the failure of startups is the lack of a management team. The founders of many startups are all technically motivated. They only believe that "if a better mousetrap is invented, there will have a market."

The fourth is the opportunity. The famous American entrepreneur Bill Gross has compared the case of more than 100 companies he founded and more than 100 companies that failed in entrepreneurship. He came to the conclusion that the primary factor for entrepreneurial failure was the opportunity. He used Airbnb as an example. Many savvy investors rejected the company because they thought that no one would rent the space at home to strangers. Obviously, the practice later proved that the idea was wrong. Airbnb's success, in addition to excellent business models, relies on the opportunity. The company came at a time when the society was at the bottom of the recession and people needed extra money, so they might be willing to overcome the resistance and rent their house to strangers.

\section{COUNTERMEASURes to Promote College STUDENTS' SELF-EMPLOYMENT}

\section{A. Strengthening Propaganda of College Students' Entrepreneurship and Advocating Entrepreneurship Spirit}

The promotion of college students' entrepreneurial spirit cannot be separated from the vigorous propaganda of the news media, and it is also inseparable from the strong support of the government, universities and families. It is necessary to increase entrepreneurial propaganda and advocate entrepreneurship. In an era where challenges and opportunities coexist, the government must vigorously strengthen the propaganda of entrepreneurial characters, play the role of the media, further update ideas and concepts in the whole society, create an entrepreneurial atmosphere, and advocate entrepreneurship spirit. At the same time, it is necessary to encourage college students to work in entrepreneurship and start a business in employment. 


\section{B. Strengthening Entrepreneurship Education and Improving the Entrepreneurial Quality for College Students}

Entrepreneurship is not limited to self-employment, but also the development and promotion of entrepreneurial spirit and comprehensive quality. The development of entrepreneurship education undoubtedly provides a new perspective and carrier for the growth of students and the improvement of comprehensive quality. Entrepreneurship education is a brand-new educational concept.

First, colleges and universities should promote entrepreneurship spirit, educate students on entrepreneurship concepts, actively promote entrepreneurial and innovative academic atmosphere, and make students deeply aware of the importance and feasibility of entrepreneurship.

Second, colleges and universities should set up entrepreneurship education courses, mainly focusing on the training and education of entrepreneurial foundation, practical knowledge and entrepreneurial choice, cultivating students' entrepreneurial awareness and entrepreneurial ability, and guiding students to start their own businesses.

Third, colleges and universities should actively carry out entrepreneurial practice.

\section{Improving the Policy System for College Students to Start Their Own Businesses}

First, it is necessary to improve the entrepreneurial service policy for college students. China's entrepreneurial service policy for college students is not perfect, and policy implementation and operation are more difficult. Therefore, it is necessary to enhance the operability of the entrepreneurial service policy while reducing the conditions of the entrepreneurial service policy.

Second, it is necessary to improve the entrepreneurial financing policy for college students.

Third, it is necessary to establish a reward and recognition system. For example, it can establish a reward system for self-employment awards for college students, commend outstanding entrepreneurs, and give appropriate entrepreneurial subsidies to encourage college students to start their own businesses.

The problem of entrepreneurial financing is the main problem in the process of college students' entrepreneurship. However, there are problems such as implementation and supervision in the preferential policies of entrepreneurial financing. To this end, the government should formulate more perfect venture financing.

\section{Defining Entrepreneurial Motivation}

Entrepreneurship is not an easy task. Before choosing a business, college students must consider their own entrepreneurial motives, find out why they want to start a business, understand their personality traits, clarify their own entrepreneurial motives, reduce and avoid the mistakes caused by blind action.

\section{E. Choosing the Right Direction of Entrepreneurship}

Choosing the right direction for entrepreneurship is to correctly understand themselves, the market, and the company, and choose the right entrepreneurial project, entrepreneurial field, and entrepreneurial direction.

\section{F. The Improvement of College Students' Own Abilities}

1) Improving the quality: Entrepreneurship is a complicated and arduous process. It requires a high level of entrepreneurial quality, especially for entrepreneurs to have a reasonable knowledge structure. First of all, college students should have certain knowledge of management, business, taxation, investment, law and entrepreneurship and professional knowledge, so that when they start a business, they can seize their own advantages and make use of what they have learned. Second, it is necessary to cultivate some unique entrepreneurial qualities, including self-reliance, self-reliance, enterprising, will, and innovation.

2) Enriching social experience: Before starting a business, college students can take advantage of opportunities such as part-time work to carry out a large number of social practices. Without sufficient social experience and business management capabilities, it cannot stand in the market today. In addition, due to the lack of resources and marketing experience in the early stage of college students' entrepreneurship, there is no good emergency measure for various emergencies, and it is easy to be impulsive in the process of starting a business, and it will inevitably lead to the final failure.

3) Establishing a good interpersonal relationship: On the road of entrepreneurship, it is far from enough to rely solely on one's own ability, comprehensive knowledge, and excellent technology. It can't ignore one of the profitable factors in entrepreneurship - interpersonal relationship. Successful entrepreneurship comes from $70 \%$ of interpersonal relationships $+30 \%$ of knowledge. Among entrepreneurial resources, interpersonal relationships account for a large part. If entrepreneurs want to start a business, they must make friends and accumulate resources in all aspects.

\section{G. Introducing Social Resources to Create an Entrepreneurial Atmosphere for College Students}

It is necessary to reduce the threshold for college students' entrepreneurial loans, and increase the support for entrepreneurial projects. At the same time, it also should build a perfect college student entrepreneurial financial support system that covers government financial support, university student seed fund support, and private venture capital participation. The colleges and universities can introduce some social resources such as enterprises, social groups, individuals, and funds to support college students' entrepreneurial projects, and effectively create an atmosphere of "mass entrepreneurship and innovation". 


\section{CONCLUSION}

Innovation is the soul of a nation's progress and an inexhaustible motive force for the development of a country. Government departments at all levels actively explore ways to solve problems, correct some inappropriate entrepreneurial policies, and create a good environment for college students to start their own businesses. For college students who choose to start their own businesses, with the progress of the entrepreneurial process, they will face many setbacks and challenges. Therefore, college students must have a spirit of not being afraid of difficulties and setbacks, dare to challenge difficulties, strengthen their will, and make themselves go further on the road of entrepreneurship.

\section{REFERENCES}

[1] Yan Jiwen. Discussion on the Basic Mode and Path Selection of Innovative Entrepreneurship Education by College Students [J], Ability and Wisdom, 2017(17). (in Chinese)

[2] Zhao Na. A Comparative Study on the Development of College Students' Entrepreneurship Education on Both Sides of the Taiwan Straits [J], Journal of Yanbian Education College, 2013 (2). (in Chinese)

[3] Hu Yanfang, Su Xia. China University Students Career Guide, 2006 (12). (in Chinese)

[4] Jiang Xinguo, Zhang Ruoqin. The Strategic Significance of Cultivating College Students' Self-employment Ability [J]. 2009 (8). (in Chinese) 